\title{
さまざまな形状のユニットで構成された耐震補強ブロック壁の組合せ最適化 COMBINATORIAL OPTIMIZATION OF LATTICED BLOCKS COMPOSED OF VARIOUS UNIT SHAPES FOR SEISMIC RETROFIT
}

\author{
福島功太郎*, 大崎 純**, 見上知広***, 宮津裕次 $* * * *$ \\ Kotaro FUKUSHIMA, Makoto OHSAKI, Tomohiro MIKAMI \\ and Yuji MIYAZU
}

\begin{abstract}
FRP blocks are effectively used for reduction of cost and period of time for seismic retrofit of building frames, because they can be manufactured in plants and attached to the existing frame easily. The performance of shear wall consisting of FRP blocks can be improved by using unit latticed blocks of various shapes. However, if the shape of latticed blocks is optimized considering the thickness of each lattice member as continuous variable, the optimal solution has many thin members, which is not practically appropriate. In this paper, a combinatorial optimization approach is presented for shape optimization of shear wall consisting of unit blocks of various pre-determined shapes. It is shown in the numerical examples that the performances such as lateral stiffness and maximum shear force in the existing beam can be improved by optimizing the combination of units.
\end{abstract}

Keywords : Seismic retrofit, building frame, simulated annealing, latticed block, combinatorial optimization 而震改修，建築骨組，疑似焼きなまし法，格子ブロック，組合せ最適化

\section{1. はじめに}

建築骨組構造の耐震改修には, 免震, 制振, 耐震, 減築など, 様々 な方法が存在し, 最適な方法は, 個別の骨組の既存性能や用途によ って異なる。とくに, 公共建築物や事務所ビルなどでは, 事業継続 性が重要である。そのため, 施工時の振動や騒音を低減する必要が ある。

耐震壁の増設・増厚のために, 枠と格子で構成される耐震補強ブ ロックを組積する工法 1) は, 事業継続性の観点から優れた方法であ る。三輪ら 2)は, 超高強度繊維補強コンクリート (PRC) ブロック の特性を, 実験によって評価した。木村ら ${ }^{3)}$ は, ガラス繊維強化プ ラスチック (FRP) ブロックの特性を検証した。今川ら 4)は, ガラ スと鋼材で構成されるブロックをエポキシ樹脂で接着する工法を提 案した。しかし, これまでに提案されている工法では, 各耐震補強 ブロックの形状が画一化されており, 必ずしも耐震性能が優れた形 状になってない。また，ブロックの性能は単体あるいは壁の載荷実 験で検証されているものの, 既存骨組の柱・梁部材への影響が十分 に考慮されていない。

耐震補強ブロックを骨組構造としてモデル化すれば, そのトポロ ジー (部材配置) と剛性分布を最適化することが可能である。骨組 構造の最適化については, 多くの研究 5-8)が存在する。それらのほと
んどは，平面骨組を対象とし，柱，梁あるいはブレースの断面や配 置を最適化している。膜構造の取り付け部材などの部品を骨組モデ ルによって最適化した研究も存在する ${ }^{9)}$ 。

制振部材などの構造要素は, 大量生産され，作用寸る荷重や変形 が単純であるため, 最適化の効果が高いと考えられる。大崎ら 10) は，開口部を有するパネルダンパーの開口形状を最適化することに より，エネルギー消費性能を向上できることを示した。藤井ら ${ }^{11,12}$ は，制振部材を骨組構造でモデル化して形状とトポロジーを最適化 した。見上ら ${ }^{13)}$ は，鉄筋コンクリート造の既存建物の耐震補強に用 いるブロックに着目し，耐震補強ブロックを骨組部材でモデル化す ることで, 非線形計画法（逐次 2 次計画法）を用いて, そのトポロ ジーと剛性分布を最適化した。しかし，逐次 2 次計画法による最適 化では，小断面の部材が多く出現する場合もあった。

本論では, あらかじめ指定された種類のユニットで構成される耐 震補強ブロックの形状を, 組合せ最適化手法を用いて最適化する。 この手法によれば、小断面部材をあらかじめ排除することができる。 目的関数は, 補強部材の体積, 補強後の水平剛性と梁のせん断力と し, 耐震補強ブロックの補強効果の高い配置を, 離散最適化手法に より導出する。

\footnotetext{
* 広島大学大学院工学研究科建築学専攻 大学院生 (現 大成建設設計本部 修士(工学) )

** 京都大学大学院工学研究科建築学専攻 教授・博士 (工学)

*** 広島大学大学院工学研究科建築専攻 大学院生.工修 大林組本社構造設計部

**** 広島大学大学院工学研究院 助教 $\cdot$ 博士 (工学)
}

Grad. Stud., Dept. of Architecture, Hiroshima University

(Currently, Design Division, Taisei Corporation, M.Eng.)

Prof., Dept. of Architecture and Architectural Engineering, Kyoto University, Dr.Eng.

Grad. Stud., Dept. of Architecture, Hiroshima University, M.Eng.

Structural Eng. Dept., Tokyo Head Office, Obayashi Corporation

Assist. Prof., Graduate School of Engineering, Hiroshima University, Dr.Eng. 


\section{2. 既存骨組と耐震補強格子ブロックのモデル化}

Fig. 1 のような横 $2000 \mathrm{~mm}$, 縦 $1000 \mathrm{~mm}$ の枠材と縦横斜めの格 子部材からなる耐震補強格子ブロック（以降「格子ブロック」）を基 本ユニットとし, Fig. 2 に示すように, 横に 4 ユニット, 縦に 4 ユ ニット連結した 16 ユニット連結 2 次元モデルを考える。これは, 階高 $4000 \mathrm{~mm}$, スパン $8000 \mathrm{~mm}$ の既存骨組の構面を補強するため の耐震補強格子ブロック壁を想定したモデルである。既存骨組は鉄 筋コンクリート造ラーメン架構とし, 柱および梁を弾性の Beam-Column 要素でモデル化する。解析コードは, 汎用骨組解析

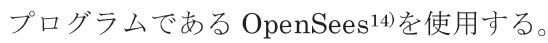

格子ブロックは FRP 製とし，枠材と格子部材を弾性の Beam-Column 要素でモデル化する。Fig. 1 は存在可能なすべての 部材の配置を示しており, この中から不要な部材を除去してさまざ まな種類のユニットブロックを作成する。既存骨組の諸元を Table 1 に，格子ブロックの枠材 (Frame) と格子部材 (Lattice) の諸元を Table 2 に示す。なお, Table 2 で Width $(B)$ はモデル面外方向の幅 を, Thickness $(T)$ はモデル面内方向の厚さを示す。以下の最適化 において, 存在する格子材の板厚を $100 \mathrm{~mm}$ とし, 存在しない場合 にも解析の便宜のため厚さ $0.1 \mathrm{~mm}$ の部材を与える。各部材は 1 つ の梁要素でモデル化するため, 個材座屈を十分な精度で表現できな いが，軸力を主に負担する斜め方向ラチス部材の細長比は，節点間 距離を座屈長さとしても24.5であり，十分に小さい。

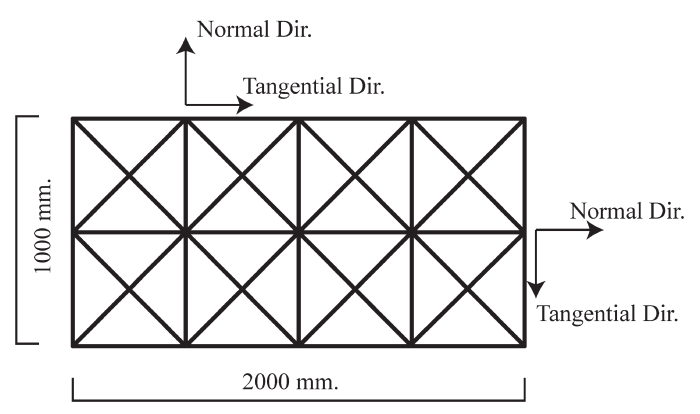

Fig. 1 Basic configuration of latticed unit block.

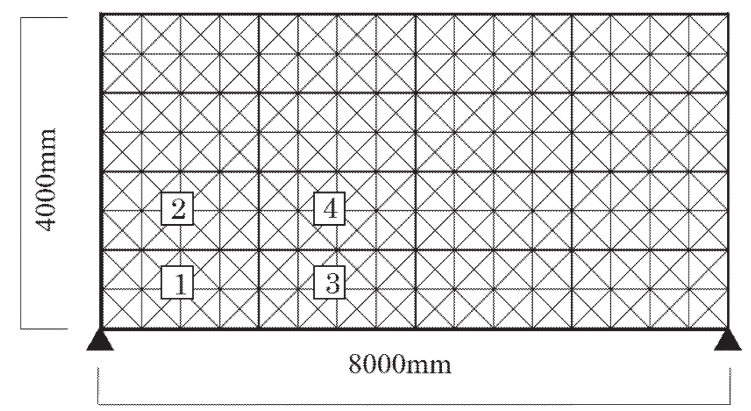

Fig. 2 Connection of blocks to existing frame.

Table 1 Specification of existing frame.

\begin{tabular}{|c|c|c|c|c|}
\hline & $\begin{array}{c}\text { Width } \\
B(\mathrm{~mm})\end{array}$ & $\begin{array}{c}\text { Depth } \\
D(\mathrm{~mm})\end{array}$ & $\begin{array}{c}\text { Cross- }_{\text {sectional area }} \\
A\left(\mathrm{~mm}^{2}\right)\end{array}$ & $\begin{array}{c}\text { Moment of } \\
\text { inertia of area } \\
I\left(\mathrm{~mm}^{4}\right)\end{array}$ \\
\hline Column & 700 & 700 & 490000 & $2.00 \times 10^{10}$ \\
\hline Beam & 400 & 700 & 280000 & $1.14 \times 10^{10}$ \\
\hline
\end{tabular}

Table 2 Specification of latticed block.

\begin{tabular}{|c|c|c|c|c|}
\hline & Width & $\begin{array}{c}\text { Thick- } \\
\text { ness } \\
T(\mathrm{~mm})\end{array}$ & $\begin{array}{c}\text { Cross- } \\
\text { sectional area } \\
A\left(\mathrm{~mm}^{2}\right)\end{array}$ & $\begin{array}{c}\text { Moment of } \\
\text { inertia of area } \\
I\left(\mathrm{~mm}^{4}\right)\end{array}$ \\
\hline Frame & 60 & 10 & 600 & $5.00 \times 10^{3}$ \\
\hline Lattice & 60 & 0.1 or 100 & 6 or 6000 & $\begin{array}{c}5.00 \times 10^{-3} \\
\text { or } 5.00 \times 10^{6}\end{array}$ \\
\hline
\end{tabular}

\section{3. 接合部のモデル化}

耐震補強ブロック節点間およびブロック節点一既存骨組間の接合 部は，接着剤（エポキシ樹脂）による結合を仮定し，接着部分は引 張側と圧縮側で異なる剛性と降伏耐力を指定できる長さ 0 の要素

(OpenSees ${ }^{14)}$ の UniaxialMaterial ElasticBilin) によりモデル化 する。そのため, 梁と柱についても, ブロックの節点上に節点を設 け, 梁は 16 個, 柱は 8 個の要素で分割する。コンクリート, エポ キシ樹脂 ${ }^{15)}, \mathrm{FRP}^{3)}$ の諸元を Table 3 に, 接着部分を模擬する要素 の法線方向（Fig. 1 参照）の特性を Fig. 3(a)に，接線方向（Fig. 1 参照）の特性を Fig. 3(b)に示す。ただし Fig. 3(a)は，正を引張，負 を圧縮とする。

接着部分の法線方向の圧縮剛性は，Fig. 3(a)に示すように，食い 込み量が接着剤厚さ（ブロック間： $5 \mathrm{~mm}$, ブロック一既存骨組間： $20 \mathrm{~mm}$ ) と等しくなった時に，急激に上昇するように設定する。

コンクリートの引張強度は, 接着剤と FRP の引張強度の 1/10 以 下である。そのため, ブロック一既存骨組間の接着に関して, 接着 剤と FRP の破壊よりも，コンクリートの破壊が先に生じると仮定 L, Fig. 3(a)の引張強度にはコンクリートの引張強度を用いる。ま た,ブロック間の接着に関して, FRPよりも接着剤の破断が先行し て生じるものとし，Fig. 3(a)の引張強度には接着剤の引張強度を用 いる。

Table 3 Material properties of concrete, epoxy and FRP.

\begin{tabular}{|c|c|c|c|c|}
\hline & $\begin{array}{c}\text { Tensile } \\
\text { strength } \\
\sigma_{\mathrm{t}}\left(\mathrm{N} / \mathrm{mm}^{2}\right)\end{array}$ & $\begin{array}{c}\text { Compressive } \\
\text { strength } \\
\sigma_{\mathrm{B}}\left(\mathrm{N} / \mathrm{mm}^{2}\right)\end{array}$ & $\begin{array}{c}\text { Shear } \\
\text { strength } \\
\sigma_{\mathrm{s}}\left(\mathrm{N} / \mathrm{mm}^{2}\right)\end{array}$ & $\begin{array}{c}\text { Young's } \\
\text { modulus } \\
\mathrm{E}\left(\mathrm{N} / \mathrm{mm}^{2}\right)\end{array}$ \\
\hline Concrete & 2.7 & 24 & 4 & 20000 \\
\hline Epoxy & 27 & - & 10 & 4000 \\
\hline FRP & 335 & 319 & - & 20000 \\
\hline
\end{tabular}

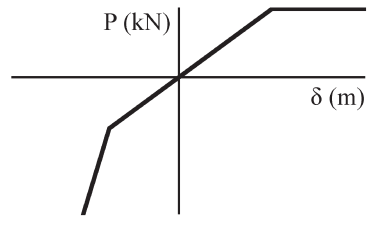

(a) Normal direction

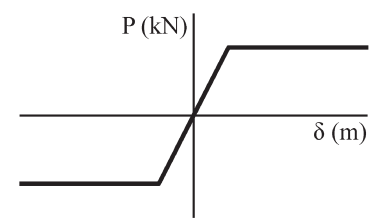

(b) Tangential direction

\section{4. 構造解析手法と最適化手法}

モデル全体の支持条件は，既存骨組の両側の柱脚でピン支持（並 進 2 方向固定, 回転 1 方向自由）とする（Fig. 2 の $\boldsymbol{\Delta}$ 印）。また，上 側梁の両端の水平変位と回転角を同一とする。

既存骨組に $1 / 200 \mathrm{rad}, 1 / 100 \mathrm{rad}$ の層間変形角に相当する強制変 位 $20 \mathrm{~mm}, 40 \mathrm{~mm}$ を与えたときの応答を, 上側梁の両端の変位増分 
を $0.4 \mathrm{~mm}$ とした解析により評価する。支持点の水平方向反力の合 計によって層せん断力を求めて，耐震壁の水平剛性を評価する。

一般に, 構造最適化の手法は, 数理計画法と発見的手法に分類さ れる。本論で対象とする耐震補強ブロック壁の最適化問題は, 複数 の格子ブロック設置可能箇所のそれぞれにユニットブロックを選択 する組合せ最適化問題である。したがって, 整数変数を容易に扱う ことができ, 制約を満たさない解が多数存在する場合にも有効な局 所探索に基づく発見的手法を用いる。その中で, 温度パラメータに 依存する確率で改悪方向への遷移を許容することで, 解が局所最適 解に陥るのを防ぎ大域最適解を求めることができる疑似焼きなまし 法16)（SA）を用いる。

本論の最適化アルゴリズムを, 目的関数を最小化する問題の場合 について以下に示す。

Step 1. 文献13)において数理計画法（逐次2次計画法）による方法 で得られた最適解に基づき，10種類のユニットブロックを定 める。格子部材のうち, 存在する部材の厚さは $100 \mathrm{~mm}$ と , 存在しない部材にも解析の簡略化のため $0.1 \mathrm{~mm}$ の厚さを与 える。枠材の厚さは $10 \mathrm{~mm}$ である。

Step 2. 耐震補強ブロックの全格子部材が存在するモデル（基準モ デル）の部材体積, 水平方向剛性, 梁の最大せん断力を, そ れぞれの基準值とする。

Step 3. 10種類のユニットブロックを, 部材体積の小さい順に 1,2 , $\ldots 10$ 整数変数で定める。ユニットブロックの $m$ 個の設置箇 所に選択されるユニットの種類を設計変数 $\mathbf{x}=\left(x_{1}, x_{2}, \ldots, x_{m}\right)$, $\left(x_{i} \in\{1,2, \ldots, 10\}\right)$ とする。

Step 4. 制約条件を満たす解を初期解とし, これを暫定解とする。 温度パラメータ $T$ に初期温度 1.0 を設定する。また，初期の ステップで目的関数が $10 \%$ 増加した時の解の受理確率が約 0.5 となるようにスケーリングパラメータ $S$ を定める。

Step 5. 上側梁両端の節点に水平方向強制変位を与えて解析を行い, 目的関数 $F(\mathbf{x})$ の值を求める。制約を満たさない場合は， $F(\mathbf{x})$ に極めて大きい值を与える。

Step 6. 現在の解候補 $\mathbf{x}$ の近傍解をランダムに 10 個生成する。近傍 解に対してStep 5 と同様の解析を行い, 最も評価が改善され

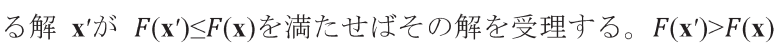
であれば, 式(1)を用いて近傍解の受理確率 $p$ を求めて, 一様 乱数 $0 \leq r \leq 1$ が $p$ 以下であれば近傍解を受理する。

$$
p=\exp \left(-\frac{\left|F\left(\mathbf{x}^{\prime}\right)-F(\mathbf{x})\right|}{T \times S}\right)
$$

Step 7. 温度更新パラメータを $\alpha<1$ とし $T \leftarrow \alpha T$ に温度を更新する。 以下の例では， $\alpha=0.92$ とする。

Step 8. 温度更新回数が指定值 50 に達していれば, それまでの最良 解を出力して終了する。指定值に達していなければ, Step 6 にもどる。

\section{5。耐震補強ブロック壁の形状最適化問題}

Fig. 2 の部分骨組を対象として, 10 種類のユニットブロックの組 合せを最適化する。Fig. 2 の部分骨組は, 多層多スパン骨組の一つ の構面であると考えて，耐震補強ブロック壁の形状が鉛直方向，水 平方向ともに対称となるように，変数をグループ化する。したがっ て, 設置箇所は Fig. 2 の 1, 2, 3, 4 の 4 箇所であり, 变数の数は $m=4$ である。

まず，Fig. 4 に示した 10 種類のユニットブロック（以降、「ユニ ットブロック群 $1 」)$ を用いて最適化を行い, 最適形状と応答量に関 して考察する。次に, ユニットブロック群 1 のうち不要であると想 定されるユニットブロックを, より補強効率が良いと考えられるユ ニットブロックに置き換え, 新たに得られたユニットブロック群を 用いて再度最適化を行う。この過程を繰り返すことで, 補強効率の 優れた耐震補強壁が創出できる。
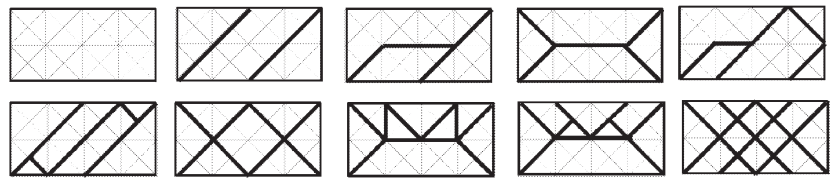

Fig. 4 Ten types of blocks in unit group 1.

耐震補強量の指標として耐震補強ブロック壁の部材体積合計（以 降，単に「部材体積」）を，而震補強効果の指標として水平方向反力 の合計（以降，単に「水平方向反力」）を，既存躯体一の影響の指標 として既存上側梁の最大せん断力を考慮し, 以下のような基準モデ ルと 3 種類の最適化問題を考える。

3 つの最適化問題は独立であるが，Problem 2 では制約条件に Problem 1 の結果を, Problem 3 では Problem 1，2 の結果を考慮 する。また, 部材の破断を避けるために, 3 つの問題全てに対して, 部材の縁応力（軸力と曲げモーメントの複合応力）の絶対值の最大 值 $\sigma_{\text {max }}$ が, Table 3 に示寸 FRP の圧縮強度 $\left(\sigma_{\mathrm{B}}=319 \mathrm{~N} / \mathrm{mm}^{2}\right)$ 以下 になる制約条件を与える。部材体積 $V$ が小さく, 水平方向反力 $R$ が大きく, 既存上側梁の最大せん断力 $Q$ が小さい耐震補強ブロック 壁の補強効率が良いといえる。なお， $R$ の下限值を $R_{\mathrm{L}}, V$ の上限值 を $V_{\mathrm{U}}$ とし, Problem 3 では Problem 1, 2 とは異なる值を用いるこ とが可能であるため，それぞれ $R_{\mathrm{L}}^{*}, V_{\mathrm{U}}^{*}$ とする。

\section{基準モデル:}

基準モデルとして，格子ブロックのすべての格子部材が存在する モデルを作成し, 部材体積 $V_{0}\left(\mathrm{~m}^{3}\right)$, 水平方向反力 $R_{0}(\mathrm{kN})$, 既存上 側梁の最大せん断力 $Q_{0}(\mathrm{kN})$, 最大縁応力 $\sigma_{0}\left(\mathrm{~N} / \mathrm{mm}^{2}\right)$ および最大 軸力 $N_{0}$ を算出する。

\section{Problem 1: 部材体積の最小化問題:}

目的関数 : 部材体積 $V(\mathbf{x})$ の最小化

制約条件 : 水平方向反力 $R(\mathbf{x}) \geq R_{\mathrm{L}}$

$$
\text { : 縁応力 } \quad \sigma_{\text {max }}(\mathbf{x}) \leq \sigma_{\mathrm{B}}
$$

Problem 2: 水平方向反力の最大化問題:

目的関数 : 水平方向反力 $R(\mathbf{x})$ の最大化 制約条件 : 部材体積 $V(\mathbf{x}) \leq V_{\mathrm{U}}$ : 縁応力 $\sigma_{\max }(\mathbf{x}) \leq \sigma_{\mathrm{B}}$ 
Problem 3: 既存上側梁の最大せん断力の最小化問題:

目的関数 : 既存上側梁の最大せん断力 $Q(\mathbf{x})$ の最小化

制約条件: 水平方向反力 $R(\mathbf{x}) \geq R_{\mathrm{L}}^{*}$

$\begin{array}{ll}\text { : 部材体積 } & V(\mathbf{x}) \leq V_{\mathrm{U}}^{*} \\ \text { : 縁応力 } & \sigma_{\text {max }}(\mathbf{x}) \leq \sigma_{\mathrm{B}}\end{array}$

\section{6. 耐震補強ブロック壁の形状最適化結果}

Fig. 4 に示したユニットブロック群 1 を用いて得られた各問題の 最適化結果を示す。以降に示す変形図では, 変形後の部材配置を明 瞭化するため, 変位を 5 倍とし, 既存骨組を省略している。各問題 は凸な最適化問題ではないため, SA によって得られる解は初期解 に依存する。したがって, Problem 1 では制約条件を満たす 5 個の 異なるランダムな解を初期解として最適化を行う。Problem 2, 3 で は，ランダムに生成した解は制約を満たさない場合が多いため, Problem 1 の最適解を初期解とし, 近傍解を生成する際の乱数の初 期值を変更する。それぞれの問題に対して, 5 回の最適化で得られ た解のうち最も優れた解を以下に示す。

以下の結果の表記において, 層間変形角 $1 / 200 \mathrm{rad}$ と 1/100 rad に対する值を，括弧を用いて（応答 1 , 応答 2 ) のように表記する。

\section{1 ユニットブロック群 1}

\section{・基準モデル}

層間変形角(1/200 rad, 1/100 rad)に対する基準モデルの解析結果 を Table 4, 形状を Fig. 5(a), 軸力の絶対值を Fig. 5(b),(c)に示す。 軸力図より, 縦横方向の格子部材よりも, 斜め方向の格子部材の補 強効果が高いことが認められる。部材の軸力は，それぞれの部材の 効率を示しており, 次節のユニットブロック群 2 のユニット形状の 選択基準とすることができる。また，接触要素の特性が圧縮と引張 で非対称なため，軸力分布は非対称となっている。

Table 4 Response of reference model.

\begin{tabular}{|c|c|c|c|c|c|}
\hline $\begin{array}{c}\text { Drift } \\
\text { angle }\end{array}$ & $\begin{array}{c}V_{0} \\
\left(\mathrm{~m}^{3}\right)\end{array}$ & $\begin{array}{c}R_{0} \\
(\mathrm{kN})\end{array}$ & $\begin{array}{c}Q_{0} \\
(\mathrm{kN})\end{array}$ & $\begin{array}{c}\sigma_{0} \\
\left(\mathrm{~N} / \mathrm{mm}^{2}\right)\end{array}$ & $\begin{array}{c}N_{0} \\
(\mathrm{kN})\end{array}$ \\
\hline $1 / 200$ & 1.62 & 3282 & 489 & 52 & 208 \\
\hline $1 / 100$ & 1.62 & 4134 & 921 & 118 & 258 \\
\hline
\end{tabular}

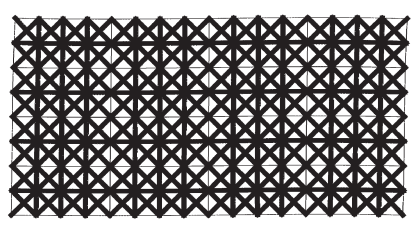

(a) thickness

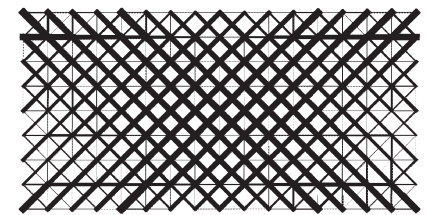

(b) axial force for $1 / 200$

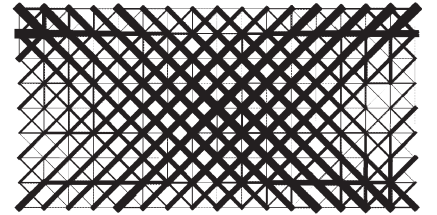

(c) axial force for $1 / 100$
Fig. 5 Reference model.

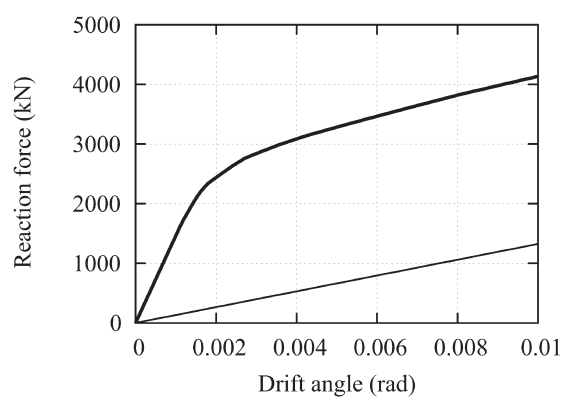

Fig. 6 Horizontal reaction force of reference model and frame model without block.

Fig. 6 には，基準モデルと格子ブロックを有さない既存骨組につ いて，層間変形角と水平方向反力の関係を太線と細線でそれぞれ示 す。基準モデルでは，約 $1 / 500 \mathrm{rad}$ で格子ブロックと既存骨組の接 合部で引張力を受けるコンクリートが破壊し，1/500 rad 以降の水 平方向反力の増大には，既存骨組の剛性の寄与が極めて大きい。す なわち，基準モデルでは，格子ブロックの剛性が $1 / 500 \mathrm{rad}$ 以降の 水平剛性（接線剛性）にほとんど寄与していない。

以下では，ユニットブロック群 1 を用いて, Problem 1 3 の最適 化を行う。

\section{- Problem1（部材体積最小化問題）}

層間変形角(1/200 rad, 1/100 rad)の部材体積最小化問題に対する 水平方向反力 $R(\mathrm{x})$ の下限值 $R_{\mathrm{L}}$ は，基準モデルの值 $R_{0}$ の約 $70.0 \%$ に 相当する $(2297 \mathrm{kN}, 2894 \mathrm{kN})$ とする。最適化によって得られた解の応 答量を Table 5 に示す。ここで， $N_{\max }$ は格子部材の軸力の絶対值の 最大值である。また, 目的関数の值をグレーの網掛けで示している。 而震補強ブロック壁の形状を Fig. 7(a),(c)に, 軸力の絶対值を Fig. $7(\mathrm{~b}),(\mathrm{d})$ に示す。

最適化の結果, 層間変形角 $(1 / 200 \mathrm{rad}, 1 / 100 \mathrm{rad})$ に対し, 水平方 向反力が基準モデルから $(70.0 \%, 74.1 \%)$ に低下しているものの，部 材体積を $(29.2 \%, 24.3 \%)$ まで低減できており，水平剛性が $70 \%$ 以上 で部材体積を 30\%以下に低減した耐震補強ブロック壁形状が得ら れている。

Table 4, 5 より，1/100 rad の方が 1/200 radよりも部材体積の減 少量が大きい。Fig. 6 からわかるように，水平方向反力の制約を満 たすために, 格子ブロックにより増大させるべき水平剛性の割合は, $1 / 200 \mathrm{rad}$ に比べ 1/100 rad の方が小さい。付与す心゙き水平方向反力 は 1/200 radの場合, 既存骨組モデル（ブロックのないモデル）の 水平方向反力 $(662 \mathrm{kN})$ の $247 \%(1635 \mathrm{kN})$ であり，1/100 rad の場合, 既存骨組モデルの水平方向反力（1325kN）の 118\%（1569 $\mathrm{kN}$ ）である。したがって，格子ブロックの総体積と水平方向反力と の関係に正の相関があるとすれば，1/100 radの場合の方が付加す べき格子ブロックの体積は小さくなり，このことが，1/100 rad と 1/200 radの部材体積の減少率の差異の一因と考えられる。

$N_{\max }$ の值は各基準モデルの(1.46 倍, 1.53 倍)である。1/100 rad で の $\sigma_{\max }$ の值は $175 \mathrm{~N} / \mathrm{mm}^{2}$ であり, FRP の圧縮強度の $1 / 2$ 程度であ る。最適形状は, 縦材・横材を排除して斜材を主に用いた形状とな っている。また, 斜材の軸力が増加して補強効率が良くなっている ことが確認できる。 

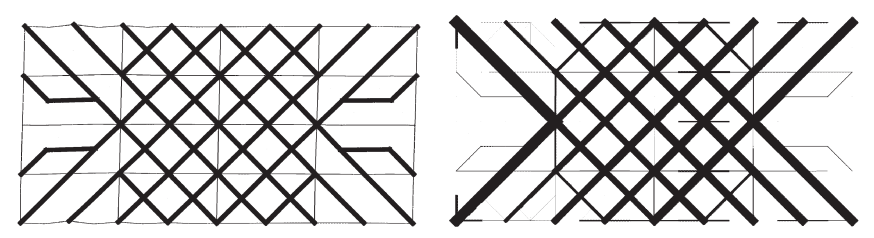

(a) local optimal solutions for $1 / 200$

(b) axial force for $1 / 200$

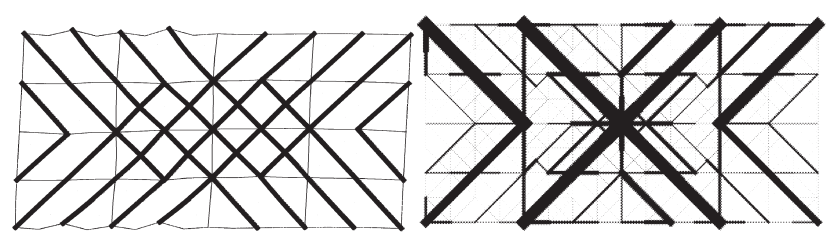

(c) local optimal solutions for 1/100

(d) axial force for $1 / 100$

Fig. 7 Optimal shapes and axial forces of Problem 1 (Group 1).

\begin{tabular}{|c|c|c|c|c|c|}
\hline Drift angle & $V\left(\mathrm{~m}^{3}\right)$ & $R(\mathrm{kN})$ & $Q(\mathrm{kN})$ & $\sigma_{\max }\left(\mathrm{N} / \mathrm{mm}^{2}\right)$ & $N_{\max }(\mathrm{kN})$ \\
\hline $1 / 200$ & 0.473 & 2299 & 400 & 104 & 303 \\
\hline $1 / 100$ & 0.398 & 3063 & 628 & 175 & 396 \\
\hline
\end{tabular}

$\mathrm{SA}$ による最適化の精度を確認するために, $10^{4}=10000$ 個の解を 総列挙した結果, 層間変形角が $1 / 100 \mathrm{rad}$ と $1 / 200 \mathrm{rad}$ の両方の場 合で Table 5 の解が大域最適解であることが確認できた。以下のユ ニットブロック群 2 についても, Problem 1 の解が大域最適解であ ることを確認した。したがって, Problem 2, 3 についてもステップ 数 50 の SAによって最適解を求める。

以下で示寸ユニットブロック群 1,2 の Problem 1 3の 5 回のす ぶての試行について, SA での最適解が得られたステップ数を Table 6 に示す。ここで,「一」は最適解が得られなかったことを示してい る。Table 6 より, 全ての問題において, 5 回の試行のいずれかで, 21 ステップ以内で最適解が得られていることがわかる。したがって, ステップ数は 50 で十分であり, 近傍数が 10 なので, 各問題での解 析回数は, 5 回の試行を行った場合 $(50 \times 10+1) \times 5=2505$ である。

Table 6 Number of steps to obtain optimal solution.

\begin{tabular}{|c|c|c|c|c|c|c|c|}
\hline & & & \multicolumn{5}{|c|}{ Trial } \\
\hline $\begin{array}{l}\text { Unit } \\
\text { Group }\end{array}$ & Problem & $\begin{array}{l}\text { Drift } \\
\text { angle }\end{array}$ & 1 & 2 & 3 & 4 & 5 \\
\hline \multirow{6}{*}{1} & \multirow{2}{*}{1} & $1 / 200$ & 5 & 5 & 10 & 29 & 15 \\
\hline & & $1 / 100$ & 18 & 11 & 6 & 15 & 4 \\
\hline & \multirow{2}{*}{2} & $1 / 200$ & 8 & 19 & 4 & 6 & 27 \\
\hline & & $1 / 100$ & 5 & 11 & 8 & - & 5 \\
\hline & \multirow{2}{*}{3} & $1 / 200$ & 3 & 4 & 3 & 1 & - \\
\hline & & $1 / 100$ & 23 & 11 & 29 & 12 & 22 \\
\hline \multirow{6}{*}{2} & \multirow{2}{*}{1} & $1 / 200$ & 4 & 10 & - & - & 6 \\
\hline & & $1 / 100$ & 16 & - & - & - & - \\
\hline & \multirow{2}{*}{2} & $1 / 200$ & 5 & 2 & 12 & 5 & - \\
\hline & & $1 / 100$ & - & 6 & - & 6 & 7 \\
\hline & \multirow{2}{*}{3} & $1 / 200$ & - & 20 & 21 & - & - \\
\hline & & $1 / 100$ & - & - & 7 & - & - \\
\hline
\end{tabular}

- Problem 2 (水平方向反力最大化問題)

Problem 1 で得られた最適解の部材体積 $\left(0.473 \mathrm{~m}^{3}, 0.398 \mathrm{~m}^{3}\right)$ よ り $10 \%$ 大きい值 $\left(0.520 \mathrm{~m}^{3}, \quad 0.438 \mathrm{~m}^{3}\right)$ を部材体積 $V(\mathbf{x})$ の上限值 $V_{\mathrm{U}}$ とした場合の最適化結果を Table 7 に示す。また, 最適化で得ら れた形状を Fig. 8(a),(c)に，軸力の絶対值を Fig. 8(b),(d)に示す。

Table 7 より, 基準モデルに対し, 層間変形角を(1/200 rad, 1/100 $\mathrm{rad})$ とした場合で水平方向反力は $(72.7 \%, 74.5 \%)$ であり, Problem 1 の最適解より少し大きい。部材体積の值は上限值を少し下回ってい る。その結果, Problem 1 の解から Problem 2 の解への反力の増加 量は, Problem 1 の值の $(3.7 \%, 0.5 \%)$ であり, Problem 1, 2 の解に それほど差異はないといえる。すなわち，部材体積と水平方向反力 はトレードオフ関係にあり，Vの上限值あるいは $R$ の下限值が適切 に与えられれば，Problem 1 と 2 のいずれを解いてもよい。

Table 7 Result of Problem 2 (Group 1).

\begin{tabular}{|c|c|c|c|c|c|}
\hline Drift angle & $V\left(\mathrm{~m}^{3}\right)$ & $R(\mathrm{kN})$ & $Q(\mathrm{kN})$ & $\sigma_{\max }\left(\mathrm{N} / \mathrm{mm}^{2}\right)$ & $N_{\max }(\mathrm{kN})$ \\
\hline $1 / 200$ & 0.517 & 2385 & 427 & 94 & 292 \\
\hline $1 / 100$ & 0.434 & 3079 & 583 & 284 & 336 \\
\hline
\end{tabular}
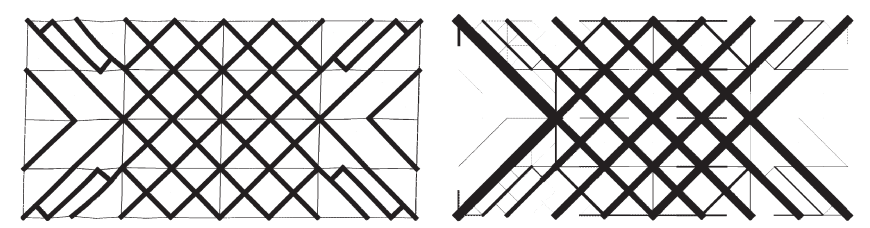

(a) local optimal solutions for $1 / 200$

(b) axial force for $1 / 200$
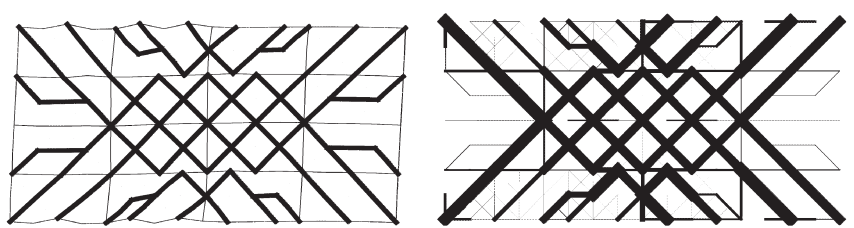

(c) local optimal solutions for $1 / 100$

(d) axial force for $1 / 100$

Fig.8 Optimal shapes and axial forces of Problem 2 (Group 1).

\section{· Problem 3 (既存上側梁最大せん断力最小化問題)}

制約条件として与える水平方向反力 $R(\mathrm{x})$ の下限值 $R_{\mathrm{L}}^{*}$ は, Problem 2 の最適解での值の $(85 \%, 80 \%)$ の值 $(2027 \mathrm{kN}, 2463 \mathrm{kN})$ とする。また，部材体積 $V(\mathbf{x})$ の上限值 $V_{\mathrm{U}}^{*}$ は Problem 2 と同じで ある。最適化によって得られた解の応答量を Table 8 に示寸。また, 耐震補強ブロック壁の形状を Fig. 9(a),(c)に，軸力の絶対值を Fig. 9(b),(d)に示す。

最適化の結果, 部材体積は $(28.8 \%, 26.7 \%)$ であり, 水平方向反力 合計は $(69.9 \%, 61.1 \%)$ である。また， $N_{\max }$ の值は，各基準モデルの (1.44 倍, 1.73 倍)である。

既存上側梁の最大せん断力は，基準モデルの $(81.8 \%, 55.6 \%)$ に低 下しているが，1/200 rad では Problem 1 から改善されていない。 したがって, 上側梁の最大せん断力は, 層間変形角が大きいほど低 減効果が大きくなる傾向にあり，1/100 rad では，部材体積を $30 \%$ 以下に低減して既存上梁最大せん断力を $45 \%$ 程度低減できるよう な耐震補強ブロック壁形状が得られた。 
Table 8 Result of Problem 3 (Group 1).

\begin{tabular}{|c|c|c|c|c|c|}
\hline Drift angle & $V\left(\mathrm{~m}^{3}\right)$ & $R(\mathrm{kN})$ & $Q(\mathrm{kN})$ & $\sigma_{\max }\left(\mathrm{N} / \mathrm{mm}^{2}\right)$ & $N_{\max }(\mathrm{kN})$ \\
\hline $1 / 200$ & 0.466 & 2294 & 400 & 107 & 299 \\
\hline $1 / 100$ & 0.432 & 2524 & 512 & 219 & 446 \\
\hline
\end{tabular}
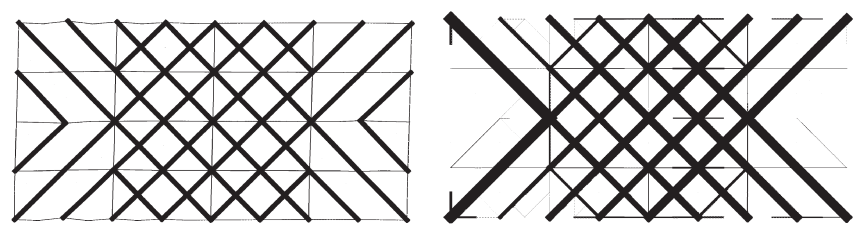

(a) local optimal solutions for $1 / 200$

(b) axial force for $1 / 200$
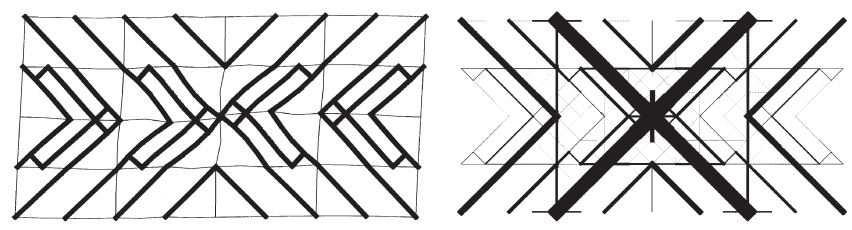

(c) local optimal solutions for $1 / 100$

(d) axial force for $1 / 100$

Fig. 9 Optimal shapes and axial forces of Problem 3 (Group 1).

\section{2 ユニットブロック群 2}

ユニットブロック群 1 を使用した Problem 1 3 の結果より, 部材 体積が小さく, $180^{\circ}$ の回転対称性をもち, 斜材を主に用いる格子 ブロックが選択される傾向にあることを確認できる。また, 軸力図 より，軸力を十分に負担していない格子部材があることがわかる。

そこで, ユニットブロック群 1 の結果を考慮して, 部材体積が $0.0525 \mathrm{~m}^{3}$ 以上のブロックを排除し, 対称性, 連結性, 部材体積を考 慮した格子ブロック群を作成する。10 種類のユニットブロックのう ち, 5 種類は, 部材体積を可能な限り小さくし, 連結性を向上させ ることを目的とする。残りの 5 種類の格子ブロックは, 部材体積の 小さな格子ブロックと連結可能であり, 部材体積を一定以上確保し, 水平方向反力を高めることを目的とする。以上の方針で得られた 10 種類の格子ブロック (以降, 「ユニットブロック群 $2 」$ ) を Fig. 10 に 示寸。ユニットブロック群 2 を用いて, 再度 Problem 1 3 の最適化 を行う。
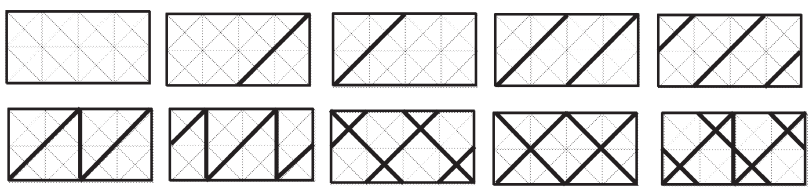

Fig.10 Ten types of blocks in unit group 2 .

\section{• Problem1（部材体積最小化問題）}

水平方向反力 $R(\mathrm{x})$ の下限值は, ニニットブロック群 1 の最適化問 題と同じ值と寸る。最適化によって得られた解の応答量を Table 9 に, 而震補強ブロック壁の形状を Fig. 11(a)(c)に, 軸力の絶対值を Fig. 11(b)(d)に示寸。

最適化の結果, 層間変形角(1/200 rad, 1/100 rad)に対して水平方 向反力合計が基準モデルの $(70.9 \%, 70.1 \%)$ に低下しているものの, 部材体積を(28.1\%, 21.2\%)まで低減できた。最大軸力は, 基準モデ ルの(1.49 倍, 1.73 倍)であり, 部材が効率よく用いられていること
がわかる。また，部材体積は，ユニットブロック群 1 の $(96.4 \%$, 86.4\%)であり，ユニットブロック群 2 の有効性を確認できる。

Table 9 Result of Problem 1 (Group 2).

\begin{tabular}{|c|c|c|c|c|c|}
\hline Drift angle & $V\left(\mathrm{~m}^{3}\right)$ & $R(\mathrm{kN})$ & $Q(\mathrm{kN})$ & $\sigma_{\max }\left(\mathrm{N} / \mathrm{mm}^{2}\right)$ & $N_{\max }(\mathrm{kN})$ \\
\hline $1 / 200$ & 0.456 & 2326 & 390 & 101 & 309 \\
\hline $1 / 100$ & 0.344 & 2898 & 580 & 199 & 446 \\
\hline
\end{tabular}
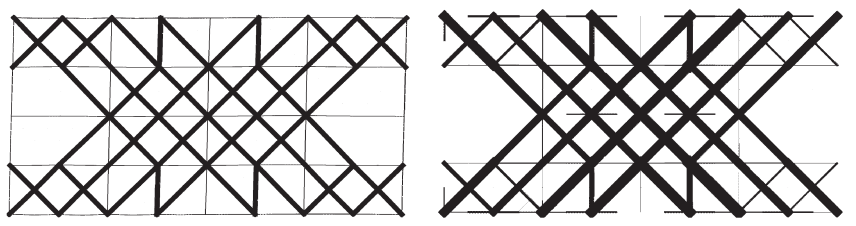

(a) local optimal solutions for $1 / 200$

(b) axial force for $1 / 200$
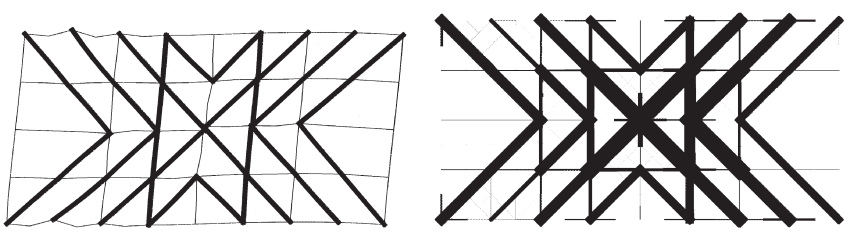

(c) local optimal solutions for $1 / 100$

(d) axial force for $1 / 100$

Fig.11 Optimal shapes and axial forces of Problem 1 (Group 2).

\section{- Problem 2（水平方向反力最大化問題）}

Problem 1 で得られた最適解の部材体積 $\left(0.456 \mathrm{~m}^{3}, 0.344 \mathrm{~m}^{3}\right)$ より $10 \%$ 大きい值 $\left(0.502 \mathrm{~m}^{3}, 0.378 \mathrm{~m}^{3}\right)$ を部材体積 $V(\mathbf{x})$ の上限値 $V_{\mathrm{U}}$ と した場合の最適化結果を Table 10 に, 耐震補強ブロック壁の形状を Fig. 12(a),( c)に，軸力の絶対值を Fig. 12(b),(d)に示す。

最適化の結果, 基準モデルに対し, 部材体積合計を(30.9\%,21.9\%) に低減させ, 水平方向反力の低下を $(75.2 \%, 75.0 \%)$ に留めることが できた。軸力の最大值は，基準モデルの(1.34 倍， 1.77 倍)である。 また, ユニットブロック群 1 と比較して, 水平方向反力が少し増加 している。

Table 10 Result of Problem 2 (Group 2).

\begin{tabular}{|c|c|c|c|c|c|}
\hline Drift angle & $V\left(\mathrm{~m}^{3}\right)$ & $R(\mathrm{kN})$ & $Q(\mathrm{kN})$ & $\sigma\left(\mathrm{N} / \mathrm{mm}^{2}\right)$ & $N_{\max }(\mathrm{kN})$ \\
\hline $1 / 200$ & 0.500 & 2467 & 398 & 106 & 278 \\
\hline $1 / 100$ & 0.354 & 3100 & 523 & 247 & 456 \\
\hline
\end{tabular}
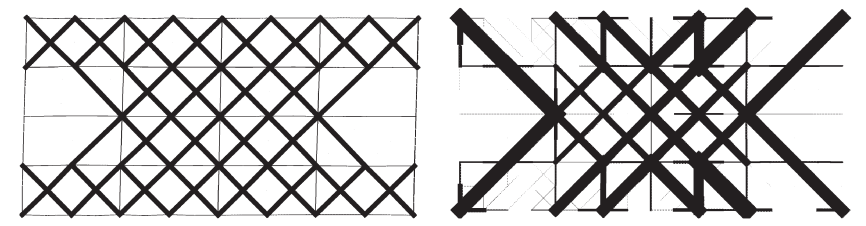

(a) local optimal solutions for $1 / 200$

(b) axial force for $1 / 200$
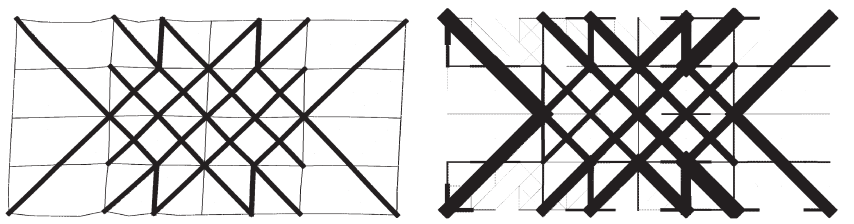

(c) local optimal solutions for $1 / 100$

(d) axial force for $1 / 100$

Fig.12 Optimal shapes and axial forces of Problem 2 (Group 2). 


\section{· Problem 3（既存上側梁最大せん断力最小化問題）}

制約条件として与える水平方向反力 $R(\mathrm{x})$ の下限值 $R_{\mathrm{L}}{ }^{*}$ は, Problem 2 の最適解での值の(85\%, 80\%)の值(2093 kN, $2480 \mathrm{kN})$ とする。また，部材体積 $V(\mathbf{x})$ の上限值 $V_{\mathrm{U}}^{*}$ は Problem 2 と同じで ある。最適化によって得られた解の応答量を Table 11 に, 耐震補強 ブロック壁の形状を Fig. 13(a),(c)に，軸力の絶対值を Fig. 13(b),(d) に示す。最適化の結果, 基準モデルに対し部材体積を(30.9\%, 22.7\%) に減少させ，水平方向反力を $(72.7 \%, 62.6 \%)$ に維持し，既存上側梁 の最大せん断力を $(62.4 \%, 42.5 \%)$ に低減することができた。軸力の 最大值は，基準モデルの(1.37 倍, 1.85 倍)である。

上側梁せん断力の最大值は，ユニットブロック群 1 の場合の (76.3\%, 76.4\%)であり，ユニットブロック群 2 は梁せん断力の低減 のためにも有効である。

Table 11 Result of Problem 3 (Group 2).

\begin{tabular}{|c|c|c|c|c|c|}
\hline Drift angle & $\mathrm{V}\left(\mathrm{m}^{3}\right)$ & $\mathrm{R}(\mathrm{kN})$ & $\mathrm{Q}(\mathrm{kN})$ & $\sigma_{\max }\left(\mathrm{N} / \mathrm{mm}^{2}\right)$ & $N_{\max }(\mathrm{kN})$ \\
\hline $1 / 200$ & 0.500 & 2385 & 305 & 151 & 284 \\
\hline $1 / 100$ & 0.368 & 2587 & 391 & 231 & 478 \\
\hline
\end{tabular}

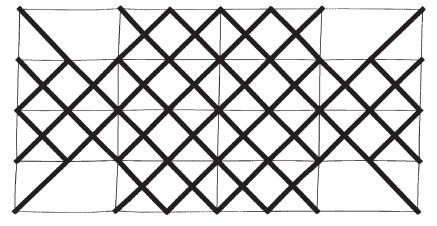

(a) local optimal solutions for $1 / 200$

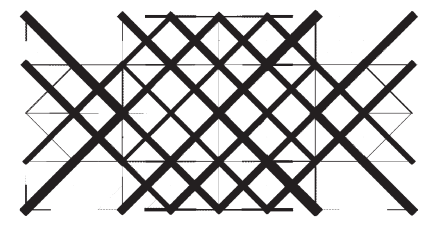

(b) axial force for $1 / 200$

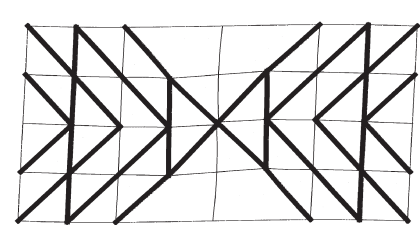

(c) local optimal solutions for $1 / 100$

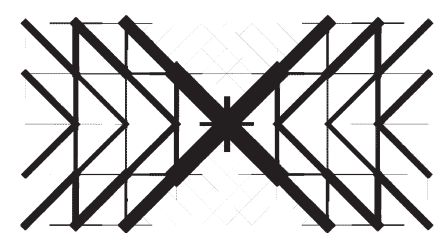

(d) axial force for $1 / 100$
Fig.13 Optimal shapes and axial forces of Problem 3 (Group 2).

以上より、ユニットブロック群 1 よりも，ユニットブロック群 2 が耐震補強の効果が高いといえる。また, ユニットブロックの形状 が，最適解に対して大きく影響することも確認できる。

\section{7. まとめ}

本論で得られた成果は以下のようにまとめられる。

1. 格子ブロックに要求されるさまざまな力学性能や部材体積を 目的関数と制約条件に与えて最適化を実行することにより，そ れぞれの設計条件に対して最適な耐震補強ブロック壁の形状 が得られる。

2. 本手法を用いることで, 格子ブロックの剛性を確保しながら軽 量化を図り，既存骨組への影響についても考慮した耐震補強ブ ロック壁の設計が可能となる。

3. 実務設計への適用を考えると, さまざまな性能を同時に制約し た最適化問題を考える必要がある。しかし, 各性能の上下限值 をあらかじめ指定することが困難な場合には, 本論で示したよ うな段階的な最適化が有効である。
4. 局所探索法の一つである疑似焼きなまし法は，本論で対象とし たような解析のために多くの計算量を必要とする組合せ最適 化問題に対して有効である。

5. 最適解として得られる耐震補強ブロック壁の形状は，用いるユ ニットブロック群に大きく依存しており，異なるユニットブロ ック群を用いることで, さまざまな最適解を得ることが可能で ある。

本研究成果を実務設計に利用するために，今後の課題として，既 存骨組の塑性化の影響を考慮するとともに，複数の設計条件の下で の多目的最適化問題を考える必要がある。

\section{謝辞}

本研究の一部は, 平成 28 年度科学研究費補助金 (基盤研究 (B) 課 題番号 $16 \mathrm{H} 04449$ ，代表 大崎 純）の助成を受けて実施した。ここ に記して謝意を表する。

\section{参考文献}

1）栗田康平，表佑太郎，江戸宏彰，古屋則之，小柳光生，増田安彦：小型 プレキャストブロックを用いた増設耐震壁工法の開発, 日本建築学会大会 学術講演梗概集, C-2, pp.139-140, 1998.

2）三輪明広, 荒井豊人, 古田島清彦, 菊田繁美, 石岡 拓 : RPC ブロック を用いた耐震補強工法に関する実験的研究，日本建築学会大会学術講演梗 概集，C-2，pp.559-560，2005

3）木村耕三，萩尾浩也，奥田章子，系日谷剛，田澤 仁：FRP ブロックを 用いた増設耐震壁工法の開発，日本建築学会大会学術講演梗概集，C-2, pp.677-678, 2004 .

4）今川聖英，今川憲英，小西周介，佐藤和真，上野裕亮，勝田勇人，内山 宏：ガラスと鋼製格子と非線形素材によるハイブリッド耐震システム （ISGW）の研究, 日本建築学会大会建築デザイン発表梗概集, pp.1007-1008, 2008.

5) M. Ohsaki: Optimization of Finite Dimensional Structures, CRC Press, 2010.

6) 澤田樹一郎, 中村雄治, 松尾 彰 : 反復線形計画法を用いた平面ラーメ ンの最適弾性 - 塑性設計法, 日本建築学会構造系論文集, No. 485, pp. $117 \cdot 125,1996.7$

7）山川 誠, 荒木慶一, 中川佳久, 上谷宏二 : ベイズ情報量規準によりパ ラメータの事前分布を考慮した鋼構造骨組最適設計法，日本建築学会構造 系論文集，No. 645, pp. 2021-2028, 2009.11

8）吉富信太，山川誠，上谷宏二：二段階緩和法に基づく鋼構造骨組の最適 離散断面選択法，日本建築学会構造系論文集，No. 586，pp. 95-100, 2004.12

9) M Ohsaki, T. Nakajima, J. Fujiwara and F. Takeda: Configuration optimization of clamping members of frame-supported membrane structures, Eng. Struct., Vol. 33, pp. 3620-3627, 2011.

10）野添順規，大崎 純，渡邊 秀和 : 有限要素解析と発見的手法によるせん 断型鋼板ダンパーの最適化, 日本建築学会構造系論文集, Vol. 78, No. 689, pp. 1247-1252, 2013.7 .

11）藤井大地, 原田卓哉, 平田裕一: 骨組の位相最適化手法を用いたリンク 機構の創生，日本建築学会構造系論文集，No. 597,pp. 63-68, 2005.11

12）藤井大地，谷澤毅：連続体の位相最適化手法を用いた制震機構の創生, 日本建築学会構造系論文集, No. 619, pp. 73-79, 2007.9

13）見上知広，大崎 純，福島功太郎：建築骨組の耐震補強格子ブロックの 形状最適化, 日本建築学会構造系論文集, Vol. 80, No. 715, pp. 1427-1434, 2015.9 .

14) Open System for Earthquake Engineering Simulation (Open Sees), PEERC, UCB, 2006. (http://opensees.brekeley.edu/) （参照 2015.2.16)

15）エポキシ注入工法,アルファ工業（ALPHA KOGYO） http://www.alpha-kogyo.com/menu06/, (参照 2016.2.16)

16）相吉英太郎, 安田恵一郎 編：メタヒューリスティックスと応用, オー 么社, 2007 . 


\title{
COMBINATORIAL OPTIMIZATION OF LATTICED BLOCKS COMPOSED OF VARIOUS UNIT SHAPES FOR SEISMIC RETROFIT
}

\author{
Kotaro FUKUSHIMA* , Makoto OHSAKI**, Tomohiro MIKAMI*** \\ and Yuji MIYAZU $U^{* * * *}$ \\ * Grad. Stud., Dept. of Architecture, Hiroshima University \\ (Currently, Design Division, Taisei Corporation, M.Eng.) \\ ** Prof., Dept. of Architecture and Architectural Engineering, Kyoto University, Dr.Eng. \\ *** Grad. Stud., Dept. of Architecture, Hiroshima University, M.Eng. \\ Structural Eng. Dept., Tokyo Head Office, Obayashi Corporation \\ **** Assist. Prof., Graduate School of Engineering, Hiroshima University, Dr.Eng:
}

Seismic performance of an existing building frame can be improved using various devices such as shear walls, shear dampers, buckling restrained brace, base isolator, etc. If we construct shear walls using latticed blocks, we can have much ventilation and transparency compared with the solid walls. In our previous study, we presented a nonlinear programming approach to optimize the topology of latticed blocks to maximize the horizontal stiffness, and also to minimize the increase of shear force in the existing beam. However, it has been found that very thin members exist in the optimal solutions, if the thicknesses of members are considered as continuous variables.

In this study, a combinatorial optimization approach is presented for topology design of a latticed shear wall. The existing beams and columns, as well as the lattice members in blocks, are modeled using beam elements. The connections between the latticed blocks as well as those between the blocks and existing members are modeled using the zero-length bi-linear elastic elements.

The response against forced shear deformation is evaluated through an incremental geometrically and materially nonlinear analysis. The types of unit blocks that can be selected are given in view of the results of optimization using the nonlinear programming approach. A heuristic approach called simulated annealing is used for optimizing combination of unit blocks.

The following three problems are solved:

1. Minimization of structural volume under constraints on horizontal stiffness and stress.

2. Maximization of horizontal stiffness under constraints on structural volume and stress.

3. Minimization of shear force of the upper beam under constraints on horizontal stiffness, structural volume, and maximum stress of lattice members.

It is confirmed through numerical examples that various optimal combinations of latticed blocks can be generated using the proposed approach. A latticed shear wall with small structural volume can be found through combinatorial optimization while maintaining the horizontal stiffness and limiting the additional force in the existing frame members. Appropriate choice of types of units that can be selected is important to obtain mechanically efficient latticed shear walls. 